\title{
OPERATIONAL OF SOLID WASTE HANDLING IN SUBANG DISTRICT
}

\author{
Nurcholis Salman \\ Department of Environmental Engineering, Faculty of Engineering, \\ Universitas Muhammadiyah Tasikmalaya, Indonesia
}

\begin{abstract}
The operational technique of waste management in Subang Regency uses simulations in the form of three scenarios, namely scenario-1 is a scenario that has been running so far (existing), in which recycling activities have not yet developed, so it is practically only a collection-transport-disposal system. a better scenario than Scenario-1, in which there are already recycling activities in the TPA, both in the formal and informal sectors (scavenging) and Based on the projections for each scenario above, it is found that Scenario-3 is a moderate scenario, because: the volume of waste transportation to the landfill is the minimum, the volume of waste that must be removed to the landfill is also the minimum which automatically has the minimum volume of landfill among the 3 (three) proposed scenarios. This scenario makes the transportation system efficient but requires a more significant investment to facilitate facilities and infrastructure. However, this is not the case in Scenario-1. In this scenario, the budget needed to procure facilities and infrastructure is relatively lighter than the needs in the other two scenarios.
\end{abstract}

Keywords: Composting, Solid Waste Operational, Subang Regency

\section{Introduction}

Most people still view waste as useless waste, not as a resource that needs to be utilized. The community in managing waste still relies on the end-of-pipe approach; namely, waste is collected, transported, and disposed of at the final waste disposal site. In fact, heaps of waste with large volumes at the landfill site can release methane gas $(\mathrm{CH} 4)$ which can cause greenhouse gas emissions and contribute to global warming. For the landfill to be decomposed through natural processes, it takes a long period and requires handling at a considerable cost.

E-mail: nurcholissalman@umtas.ac.id

Received: 3 September 2021

Revised: 16 September 2021

Accepted: 17 September 2021

DOI: $10.23969 /$ jcbeem.v5i2.4470
The new paradigm that must be embraced in our Waste Management System, it is time for local governments to change their mindset to an environmental nuance. It is time to apply the concept of integrated waste management. Minimizing waste at the source by maximizing recycling and waste utilization is a paradigm that must be embraced and become the spirit of developing the solid waste system in Indonesia. To be able to realize the vision of developing a solid waste management system, several missions are formulated as follows:

1. Reducing waste generation in the context of sustainable waste management

2. Improving the reach and quality of waste management system services

3. Empowering the community and increasing the active role of the business/private sector 
4. Improve the management and institutional capabilities in the solid waste management system following the principles of Good and Cooperative Governance.

5. Mobilize funds from various sources for the development of solid waste management systems

6. Enforce the law and complement laws and regulations to improve the solid waste management system. Presidential Decree No. 97 of 2017 on National Policies and Strategies for Household Waste Management and Household Waste is implemented from 2017 to 2025 containing: 1 . The direction of the policy of reducing and handling Household Waste and Household Waste Type 2. Strategies, programs, and targets for reducing and handling Household Waste and Household Waste.

The policy directions for reducing and handling household waste and similar household waste include improving performance in the areas of:

1. Reduction of household waste and similar household waste

2. Handling household waste and similar household waste.

Reduction of household waste and similar household waste is carried out through:

1. Limitation of the generation of household waste and similar household waste

2. Recycling of household waste and similar household waste

3. Reuse of household waste and similar household waste

The handling of household waste and similar household waste is carried out through:

1. Sorting
2. Collection

3. Freight

4. Processing

5. Final processing

Strategies for reducing household waste and similar household waste include:

1. Formulation of norms, standards, procedures, and criteria in reducing household waste and similar household waste

2. Strengthening coordination and cooperation between the central government and local governments

3. Strengthening the commitment of executive and legislative institutions at the center and regions in providing budgets for reducing household waste and waste similar to household waste

4. Capacity building of leadership, institutions, and human resources to reduce household waste and waste similar to household waste

5. Establishment of information system

6. Strengthening community involvement through communication, information, and education

7. Implementation and development of incentive and disincentive systems in reducing household waste and similar household waste

8. Strengthening the commitment of the business community through the implementation of producer obligations in reducing household waste and waste similar to household waste

The strategies for handling household waste and similar household waste are:

1. Preparation of norms, standards, procedures, and criteria 
2. Strengthening coordination and cooperation between the central government and local governments

3. Strengthening the commitment of executive and legislative institutions at the central and regional levels in providing budgets for handling household waste and waste similar to household waste

4. Capacity building for leadership, institutions, and human resources in handling household waste and similar household waste

5. Establishment of information system

6. Strengthening community involvement through communication, information, and education

7. Implementation and development of investment, operational, and maintenance schemes

8. Strengthening law enforcement

9. Strengthening the involvement of the business world through partnerships with the central government

10.Application of technology for handling household waste and waste similar to household waste that is environmentally friendly and effective

11.Implementation and development of incentive and disincentive systems in handling household waste and similar household waste.

Targets for reducing and handling household waste and similar household waste include:

1. Reduction of household waste and similar household waste by $30 \%$ (thirty percent) of the generation rate of household waste and household waste similar to household waste prior to the national policy and strategy for reducing household waste and household waste similar to household waste in 2025
2. Handling household waste and waste similar to household waste by $70 \%$ (seventy percent) of the generation rate of household waste and waste similar to household waste before the existence of national policies and strategies for handling household waste and waste similar to household waste in 2025.

3. In addition to the problem of increasing waste volume, the Subang Regency Government is currently also facing various problems related to waste management, in the form of limited operational costs and infrastructure for its management. The amount of budget issued by the Subang Regency Government to handle waste.

\section{Research Methodology}

The evaluation process of the Subang district waste management system is carried out using quantitative analysis methods, namely comparing secondary data and comparative indicators of Presidential Regulation No. 97 of 2017. Secondary data shows the existing condition of the achievements of waste management services that the Subang Regency government has carried out. The results of secondary data analysis are presented in a mass balance. Comparative indicators are achievement standards that must be met in the waste management system. The comparison results show the value that must be fulfilled in the percentage of solid waste services. So from these results it can be concluded that the current problems faced by the Subang Regency waste management system are a reference in developing a solid waste service system.

\section{Result and Discussion}

Subang Regency waste management service planning is based on the burden of waste 
problems faced in the current condition until the next 10 years, namely in 2030. The burden of waste management from 2021 to 2030, shown in volume and weight units is as in Table 1.

Table 1. The Load of Waste Management

\begin{tabular}{ccccc}
\hline \multirow{2}{*}{ Year } & \multirow{2}{*}{$\begin{array}{c}\text { Population } \\
\text { estimated }\end{array}$} & \multicolumn{3}{c}{ Waste Generated } \\
\cline { 3 - 5 } & & $\mathrm{m}^{3} /$ & \multicolumn{1}{c}{$\mathrm{m}^{3} /$} & ton/ \\
day & year & year \\
\hline 2021 & $1,619,779$ & 6,074 & $2,217.073$ & 443.415 \\
\hline 2022 & $1,633,366$ & 6,125 & $2,235.670$ & 447.134 \\
\hline 2023 & $1,646,953$ & 6,176 & $2,254.267$ & 450.853 \\
\hline 2024 & $1,660,540$ & 6,227 & $2,272.864$ & 454.573 \\
\hline 2025 & $1,674,127$ & 6,278 & $2,291.461$ & 458.292 \\
\hline 2026 & $1,687,714$ & 6,329 & $2,310.059$ & 462.012 \\
\hline 2027 & $1,701,301$ & 6,380 & $2,328.656$ & 465.731 \\
\hline 2028 & $1,714,888$ & 6,431 & $2,347.253$ & 469.451 \\
\hline 2029 & $1,728,475$ & 6,482 & $2,365.850$ & 473.170 \\
\hline 2030 & $1,742,062$ & 6,533 & $2,384,447$ & 476,889 \\
\hline
\end{tabular}

Judging from the large volume of waste that must be handled, Subang Regency is categorized as having a relatively heavy load. Moreover, with limited infrastructure and facilities as well as costs, the burden becomes heavy.

The success of a city/district waste management system is often seen from environmental cleanliness in urban areas in general. This scoring system is identical to the level of transportation of waste to the landfill. The higher the waste transported to the landfill, the cleaner the city/regency will be. The cleaner the city/regency, the more successful the City/Regency Government will be and can be felt by the community. However, this is actually only an indicator of the effectiveness of the system and can be said to be a quasi-judgment. There are still many assessment factors that should be the concern of the current City/Regency Government in waste management. Currently the demands are increasing, not only clean cities/districts but even garbage handled properly so that it does not have an impact on the environment, have begun to arise.

As for the current Subang Regency, the impact of not handling waste ideally (up to $100 \%$ ) by the Regency Government has begun to be felt. Dirty conditions in public places, that is the target of the District Government in the short term. However, it must be realized that at this time the application of the principle of saving the environment in waste management has become the mission and vision of the Regency Government. The target of clean districts with high levels of waste transportation must be balanced with efforts towards the application of the 3R (Reduce-Reuse-Recycling) concept. For this reason, in the waste management service plan for the next 10 years, 3 (three) service scenarios have been developed. The scenario emphasizes that the service burden for management actors is proportional. The management actors in question are formal managers, namely DLH (environmental agency), private managers, scavengers who are termed SIDUS (Waste Recycling Information System), independent management by the community.

Subang Regency DLH service targets are basically set based on the ability of the Government to allocate the budget every year. Bearing in mind, the size of the service to be provided will have consequences for the costs that must be provided by the Regency Government.

As for the presence of non-government managers, in waste management in Subang Regency, it is based on currently developing patterns. The ability of these parties to contribute to the improvement of services will depend on the Government's efforts and their 
facilitation. People with small capital currently dominate the presence of private managers in Subang Regency. They run a management business as an alternative livelihood. But among them, there are also those with moderate capital. Their existence needs to be appointed, seen from the achievement of relatively good work efficiency. However, their existence needs to be regulated and legally bound by the government. In an effort to promote the existence of this group, active facilitation from the government is needed. They are reached and invited to partner, with partnership patterns that have been prepared (Kawung and Tamod, 2009).

The presence of scavengers, garbage collectors in Subang Regency (SIDUS) should not be ignored. Their presence should be raised and integrated into the developed system. However, based on experience, the treatment of these groups is not to make them a formal system or formalization of informal groups, but only to facilitate their existence. The government provides opportunities so that their performance can improve, by setting up facilities at their work locations, namely at TPS and TPA. Efforts to arrange TPS in Subang Regency are conditioned to also prepare their facilities. SIDUS's performance is basically very dependent on the perpetrators and they are human workers, in addition, they also work out of necessity, so performance will be greatly influenced by these factors. Thus, the magnitude of their contribution to the increase in handled waste is considered the same for every policy on other aspects.

In the waste management system, the community is generally placed as a waste generator, so that they are the object of system services. This concept is no longer appropriate in the era of community empowerment as it is today. As the cause of the problem, the community should be the main character in solving it. Therefore, community involvement from an early age, namely since the waste management system in Subang Regency has grown, is a strategic action pattern.

Based on the potential possessed by each of the existing stakeholders, the Subang Regency Waste Management System can be run in 3 (three) scenarios. The three scenarios determine the proportion of the management burden for formal institutions.

Furthermore, the remaining waste that is not managed by formal institutions, is handed over to other stakeholder groups consisting of:

- The community as the generator by applying the principle of self-management with a target of minimizing waste transported to the landfill or even reaching 'zero waste'.

- Community management actors, or private managers, who are currently present in Subang Regency.

- Community scavengers (SIDUS).

It is proposed that there are 3 (three) scenarios for waste management, namely:

1. Scenario A: business-as-usual scenario

- There are no 3R activities at the source or in the area where the waste originates

- Waste that is served, from the temporary dumping ground is transported entirely to the landfill

- All waste that is transported to the landfill is completely backfilled/buried

2. Scenario B: moderate scenario

o There are no 3-R activities at the source or in the area where the waste originates

- Waste that is served, from the temporary dumping ground is transported entirely to the landfill 
O Some of the waste that is transported to the landfill is then processed into compost and other $3 \mathrm{R}$ activities, some of the waste along with the composting residue is taken to the landfill area to be filled/stocked. The percentage of waste transported to the landfill, and then processed into compost, is assumed to be $5 \%$ in 2021 , and will increase to $10 \%$ in 2030.

3. Scenario $\mathrm{C}$

- 3R activities start at the source of the waste or at the temporary dumping ground or in the area in the service area. The assumption is that in 2021 as much as waste is served, undergoing a $3 \mathrm{R}$ process of $5 \%$, and in 2030 it will be $10 \%$

- Other waste and residue from 3R activities, transported from temporary dumping ground to landfill location

- Some of the waste that is transported to the landfill is then processed into compost and other 3R activities, some of the waste along with the composting residue is taken to the landfill area to be filled/stocked. The percentage of waste transported to the landfill, and then processed into compost, is assumed to be $5 \%$ in 2021 , and will increase to $10 \%$ in 2030 .

Based on the existing waste data obtained regarding the current level of waste transportation services to the landfill in Subang Regency, a service improvement scenario was developed for the 10-year planning period (years 2021-2030). Existing data on the level of data waste services for 2019-2020, which reaches $50 \%$. With the plan for structuring waste facilities and infrastructure, including improvements to the operational technical system for municipal waste management, the service level can be significantly increased at the beginning of the planning year, reaching $57.5 \%$ at the end of the first stage (5 years) and increasing to $80 \%$ in the first five years. the end of the second stage ( 5 second year).

Table 2. Service Percent Increase

\begin{tabular}{ccc}
\hline Year & Estimated Population & $\%$ Served \\
\hline 2021 & $1,619,779$ & 57.5 \\
\hline 2022 & $1,633,366$ & 60 \\
\hline 2023 & $1,646,953$ & 62.5 \\
\hline 2024 & $1,660,540$ & 65 \\
\hline 2025 & $1,674,127$ & 67.5 \\
\hline 2026 & $1,687,714$ & 70 \\
\hline 2027 & $1,701,301$ & 72.5 \\
\hline 2028 & $1,714,888$ & 75 \\
\hline 2029 & $1,728,475$ & 77.5 \\
\hline 2030 & $1,742,062$ & 80 \\
\hline
\end{tabular}

Based on existing data and observations, it is shown that in the study area no significant recycling or composting efforts have been found at the source or area level carried out by both the community and other waste producers. Therefore, data on waste minimization (reduction) in 2018 in this report is listed at $0 \%$. The ideal scenario proposed above will take into account the factor of minimizing waste at the source, because the success of waste management at the source level plays an important role in the success of municipal solid waste management. In the early planning year (2021), it is assumed that there will be a will from the Regional Government and the emergence of public awareness of recycling or composting efforts at the source or regional level, and it is assumed that the minimization of waste at the source (before transportation) reaches $5 \%$. The increase in waste minimization at each planning stage (5 years) is also assumed to be the same at $2.5 \%$. 
Table 3. Waste Loaded

\begin{tabular}{ccccccc}
\multirow{nyyyyyy}{*}{ Year } & \multicolumn{2}{c}{ Scenario-A } & \multicolumn{2}{c}{ Scenario-B } & \multicolumn{2}{c}{ Scenario-C } \\
\cline { 2 - 7 } & \multicolumn{2}{c}{ (business-as-usual) } & \multicolumn{2}{c}{ (Moderate) } & \multicolumn{2}{c}{ (Ideal) } \\
\cline { 2 - 7 } $\mathbf{m}^{3} /$ year & ton/year & $\mathbf{m}^{3} /$ year & ton/year & $\mathbf{m}^{3} /$ year & ton/year \\
\hline 2021 & $2,106,219$ & 421,244 & $1,995,365$ & 399,073 & $1,773,658$ & 354,732 \\
\hline 2022 & $2,123,886$ & 424,777 & $2,012,103$ & 402,421 & $1,788,536$ & 357,707 \\
\hline 2023 & $2,141,554$ & 428,311 & $2,028,840$ & 405,768 & $1,803,414$ & 360,683 \\
\hline 2024 & $2,159,221$ & 431,844 & $2,045,578$ & 409,116 & $1,818,291$ & 363,658 \\
\hline 2025 & $2,176,888$ & 435,378 & $2,062,315$ & 412,463 & $1,833,169$ & 366,634 \\
\hline 2026 & $2,194,556$ & 438,911 & $2,079,053$ & 415,811 & $1,848,047$ & 369,609 \\
\hline 2027 & $2,212,223$ & 442,445 & $2,095,790$ & 419,158 & $1,862,925$ & 372,585 \\
\hline 2028 & $2,229,890$ & 445,978 & $2,112,528$ & 422,506 & $1,877,802$ & 375,560 \\
\hline 2029 & $2,247,558$ & 449,512 & $2,129,265$ & 425,853 & $1,892,680$ & 378,536 \\
\hline 2030 & $2,265,225$ & 453,045 & $2,146,003$ & 429,201 & $1,907,558$ & 381,512 \\
\hline
\end{tabular}

\section{Management Operating System}

Waste management operations in Subang Regency within the next 10 years are planned as follows:

1. Storage, collection and transport at the source is directed towards a segregated system. Waste is divided into 2 (two) types, namely: organic and inorganic waste. The sorting process for the first five years was only introduced, so it was oriented that a new sorting system would be formed in the last years of planning.

2. SIDUS carries out the recovery of inorganic waste that has the potential to be recycled at temporary dumping ground and landfill. DLH provides a means for the mechanism to run more optimally.

3. The operation of collecting waste from houses to temporary dumping ground is carried out by the community independently by forming an organization at the neigborhood level or appointing a private manager.

4. Transportation to the landfill is planned to use Arm Roll with steel containers. The consideration is to use Arm Roll type fleets instead of Compactors because of efficiency and operational and maintenance costs. Arm Roll is more efficient because generally the distance from temporary dumping ground to landfill Ciangir, Tamansari District in Tasikmalaya City is not too far, so there is no need for a compaction process in transporting waste. In terms of maintenance costs, Compactors require high costs, considering that there is a compaction process that causes waste with high organic content to be released, it is prone to rusting if not carried out carefully.

5. Waste composting is carried out by DLH in partnership with the private sector or other parties. Directed to apply regional-scale composting. The composting process is 
carried out as an effort to minimize waste buried in the landfill, not just to seek economic benefits. Therefore, compost production will be returned to people who are interested in using it and will also collaborate with other parties or agencies or agencies related to the use of compost products as a substitute for chemical fertilizers, for example the City Parks Service or the Agriculture Service.

6. The final disposal applies a controlled landfill system, leading to improved operations towards a sanitary landfill system in 2025 (end of stage 1).

7. The Panembong landfill is maintained and opportunities for cooperation with outside parties are sought. To increase the service life of the landfill, it is recommended to do landfill mining.

8. Incinerator as a waste destroyer is not recommended for use in Subang Regency, besides this technology is a high-cost technology, there needs to be an in-depth feasibility study for its use, considering that the composition of burnable waste in Subang Regency is still too small.

9. However, incinerators are required in handling hospital medical waste. It is hoped that every hospital in Subang Regency in the next 2 years has adequate medical waste management with the existence of individual incinerators or joint incinerators between several hospitals.

10. The waste management plan is based on the minimum amount of waste to be transported and disposed of to the landfill. The recycling of inorganic waste is carried out by empowering SIDUS, while the minimization of organic waste is carried out by carrying out composting.

11.For 10 years, the Subang Regency waste management system has been directed to handle domestic waste, namely waste originating from human activities, and not waste from a production process or waste resulting from medical activities.

12.Industrial waste, or waste resulting from the production process, is the responsibility of every institution or individual and or agency that produces it and is not the responsibility of DLH. This has been regulated by law on the management of hazardous and toxic substances (B3) from industry to be managed by a party appointed by the government.

13. The management of household hazardous and toxic substances (B3) waste, such as Insecticide packaging cans, used batteries, etc., must gradually become the responsibility of the Government. However, in its management, the 'back to producer' concept must be applied. This means that the Government is responsible for the process of recovering the waste from the city's waste generation, then the management and destruction must involve producers. Due to the long chain of household hazardous waste management systems that must be prepared, in the next 10 years the Subang Regency waste management system has not been oriented to manage it.

\section{Composting}

Based on the study of waste composition in Subang Regency, $64.50 \%$ of the waste generated in Subang Regency is suitable for composting. The source of organic waste which is quite large apart from the settlement is the market, considering that the market in Subang Regency is still a traditional market. The existing potential can be utilized by recycling organic waste into compost. The compost is a conditioning material (conditioner) loosening agricultural soil and as a means of cultivating plants or fisheries. Agricultural land around 
Subang Regency has the potential to absorb the distribution of compost, both for horticultural crops and plantation crops. Compost produced from organic waste processing must have a great opportunity to meet market demand if it has a competitive advantage over similar fertilizers. A type of compost that is commonly used in agriculture and plantations is manure.

However, based on the experience of implementing composting in several cities in Indonesia, the development of a composting system cannot be said to have economic advantages. The benefits obtained are reduced landfill loads which will extend the service life of the landfill and other benefits that are not currently being felt are benefits for saving the environment. Taking this into account, the composting business must be a policy that is not based on obtaining economic benefits.

The problem that often arises from the business of composting municipal waste is the cessation of activities because the manager feels a loss. This kind of thinking should not happen in Subang Regency. The district government must have a strong and high commitment to continue running the composting business by putting aside the desire to obtain economic benefits.

The composting process in the waste management system in Subang Regency in the short term must be considered as a learning process, considering that the DLH Subang Regency has never done it. For this reason, the capacity of the composting process is determined according to the ability at this learning stage of $10 \mathrm{~m} 3$ of waste per day, and continues to be increased to reach $100 \mathrm{~m} 3$ of waste per day by 2030 .

The target of the composting system is to reduce the burden of stockpiling at the landfill and even reduce the burden of transportation operations.
For this reason, the composting process should be carried out from the source, with the aim of reducing transportation costs. Alternative composting systems based on the location of the process can be distinguished as follows:

- Individual composting, carried out independently by each waste generator, at home or at the location where the waste is generated. For household waste, composting can be done in the yard if possible. The composting technique that can be done at home is to use the Individual Composter, which will be shown in the next report. With the application of this pattern, the generation of waste that is the burden of collection operations is reduced because $66 \%$ of the generation can be reduced by composting. However, promoting this pattern to the community takes a long time and must be programmed. Therefore, within 10 years this pattern will be included in the community empowerment program in waste management.

- Temporary dumping ground scale Communal Composting. In the implementation, the temporary dumping ground location was chosen which had sufficient land area for the composting process to be carried out. Garbage from the collection carts is sorted, then organic waste is composted at the temporary dumping ground, and the rest is transported to the landfill. In the city of Tasikmalaya, currently there is no proper temporary dumping ground to be a location for composting at the same time. For this reason, this model temporary dumping ground is prepared in the plan to add new temporary dumping ground in the next 10 years.

- Communal composting on a landfill scale. In this pattern, composting is done at the landfill site. It is intended that in the landfill there is 
an area specifically designated for composting waste or there is a special location separate from the landfill. Given the narrowness of the existing landfill area, it is recommended that this pattern of composting be carried out outside the landfill. However, when the landfill management program has been implemented, a small portion of the landfill can be allocated for the composting process.

The three alternatives above are feasible to be implemented by DLH as a learning process, but the steps that must be taken towards the implementation of a sustainable composting system are as follows:

- Establish a special unit for waste management in a formal institution or DLH

- Prepare a composting work team, which consists of sorting staff, and composting process personnel, as well as post-processing personnel. This work team is prepared by providing training.

- Make a calculation of the cost of the composting process per volume of processing load. For the composting plan in Subang Regency, with a capacity of $10 \mathrm{~m}^{3}$ per day.

- Determine the location of composting, as well as create a 'deplot'. The criteria for composting locations are as follows:

- The minimum land area is $200 \mathrm{~m}^{2}$ for 2021 . Meanwhile, to be able to accommodate a maximum capacity of $70 \mathrm{~m}^{3}$ per day in 2030 , an area of approximately $1 \mathrm{Ha}$ is needed.

- The location is far from settlements. It is possible to choose a location near a settlement, provided that the community is involved in the development of the plan and in its operation.

- The access road can be passed by an arm roll of $10 \mathrm{~m}^{3}$.
- The priority of finding a location is near the market, considering that market waste is a priority for composting.

\section{Inorganic Waste Recycling}

As in other cities, in Subang Regency, scavengers are still working on recycling inorganic waste together with a network of buying and selling goods that are informally formed. In reducing the burden of waste, the role of scavengers is very important. For this reason, the potential role of scavengers must be empowered by facilitating through the provision of facilities to collect/accommodate the products of their work. The collection facilities are placed at each temporary dumping ground location, shaped so that their presence does not interfere with the routine operation of the temporary dumping ground. Thus, the presence of scavengers will be concentrated at the temporary dumping ground location points. And in the future, with the aim of improving their performance in reducing the burden of municipal inorganic waste, it is necessary to develop an incentive mechanism.

\section{Final Disposal System}

Panembong landfill is a landfill to dispose of all Subang Regency waste. The construction and operations are still using an open dumping system, so problems due to environmental impacts will be increasingly sticking out.

Based on the evaluation of the current condition of the landfill, the priority actions needed are:

1. Arrangement of land for landfilling. The technical arrangement is directed towards controlled landfills and even sanitary landfills

2. Prepare facilities and infrastructure for controlling environmental pollution in the form of: facilities for controlling the flow and processing of leachate, pipes for collecting and distributing gas, and infrastructure for 
preventing the spread of odors, in the form of building a buffer zone (Oktariadi, 2010).

3. Arrangement of operating facilities in the form of access roads.

All the necessary actions are expensive. In the next 10 years, actions at the landfill will be prioritized for land management in the early stages to a controlled landfill accompanied by construction of optimizing the function of leachate processing ponds, leachate piping, and gas piping.

\section{Landfill Service Plan}

- The first stage is the landfill mining business, which is able to increase the availability of the Panembong landfill space. The implementation of mining requires cooperation between various parties. For this reason, a feasibility study for mining the Panembong landfill is needed in the 20212022 period.

- The second stage is when mining has been carried out optimally, then an evaluation of the recycling program needs to be carried out to measure its effectiveness and development possibilities. Suppose Subang Regency is consistent in pioneering waste management efforts with composting and SIDUS integration from 2021-2030. In that case, recycling can certainly become the main strategy for waste management in Tasikmalaya City after 2030.

\section{Conclusion}

It can be concluded, that:

- From the three scenarios, it can be seen that regardless of the proportion of the management burden assigned to DLH, it still requires the role of the other three stakeholders to achieve the most optimal level of handled waste.
- There are many advantages and disadvantages to each scenario. However, based on the principle of developing a sustainable integrated solid waste management system, Scenario-3 is more appropriate to choose. In this scenario, there is a mechanism for involving all groups that have the potential to assist the government in carrying out its obligations in realizing city cleanliness, both by recycling activities at the source level and at the landfill. In addition, the demands for the government in procuring costs are only high at the beginning of the planning year, and so from year to year are relatively minimum and evenly distributed, because they can streamline transportation costs.

\section{References}

Kabupaten Subang Dalam Angka (Subang Regency in Figures). (2020). Badan Pusat Statistik Kabupaten Subang.

Kawung, E.J. R., and Tamod, Z.E. (2009). Tingkat Kelayakan Lahan TPA Sampah Kota Manado Dalam Ukuran Mitigasi Perencanaan Lokasi TPA. EKOTON Journal, 9 (1): 1-10

Kementrian Pekerjaan Umum. (2017). Petunjuk

Teknis TPS 3R: Tempat Pengelolaan Sampah 3R. Jakarta: Direktorat Jendral Cipta Karya.

Kementrian Lingkungan Hidup dan Kehutanan. (2018). Sistem Informasi Pengelolaan Sampah Nasional. http://sipsn.menlhk.go.id/komposisi-

sampah (diakses pada tanggal 10 Maret 2021 pukul 10.31 WIB)

Oktariadi, O. (2010). Penentuan Zona Kelayakan TPA Sampah Berdasarkan Aspek Geologi Lingkungan Di Wilayah Provinsi Banten. Makalah Sosialisasi 
Geologi Lingkungan Untuk Penataan Ruang Provinsi Banten.

SNI 19-2454-2002. Tata-Tata Cara Teknik

Operasional Pengelolaan Sampah

Perkotaan.
SNI 3242-2008. Pengelolaan Sampah Di Permukiman. 